\title{
Proportions and characteristics of patients with brain abscess at Sanglah General Hospital in Denpasar, Bali, Indonesia in 2019-2020
}

\author{
Putu Satyakumara Upadhana', Ni Putu Kostarika Melia Daradila', \\ Anak Agung Bagus Putra Indrakusuma ${ }^{1}$, I Gede Krisna Arim Sadeva', \\ Putri Ayu Wulandari', I Putu Eka Widyadharma² \\ ${ }^{1}$ Bachelor of Medicine and Medical Profession Study Program, Faculty of Medicine, Udayana University, \\ Denpasar, Bali, Indonesia, \\ ${ }^{2}$ Departments of Neurology, Faculty of Medicine, Udayana University, Denpasar, Bali, Indonesia
}

\begin{abstract}
Introduction. A brain abscess is a collection of pus, immune cells, and other materials that are generally caused by bacterial or fungal infection in the brain parenchyma. This disease has a high level of morbidity and mortality, nonetheless, until now there has been no in-depth research on this disease, especially in Bali.

Objective. This study aimed to determine the proportion and characteristics of patients with brain abscess at the Sanglah General Hospital, Denpasar, Bali, Indonesia in 2019-2020.

Material and methods. This study is an observational study with a cross sectional method. A total of 41 patients with brain abscesses recorded in hospital medical records in 2019-2020 were included in this study. Univariate analysis was performed to obtain the characteristics of patients with brain abscesses.

Results. Most of the patients were male (63.4\%), aged 20-39 years. The main complaint most often found in patients was decreased consciousness $(56.1 \%)$, with neurological symptoms in the form of hemiparesis (32.3\%). Most of the abscesses were found on the right frontal, right parietal and left parietal with a percentage of $14.06 \%$ each. The CT scan results showed a rim contrast enhancement $(63.4 \%)$, cerebral edema $(75.6 \%)$, and normal sulcus gyri $(51.2 \%)$. Up to $50 \%$ of patients with a history of surgical procedures underwent a craniotomy. Other disease histories most often found in patients were sinusitis $(29.5 \%)$, diabetes mellitus $(15.3 \%)$, and toxoplasmosis $(12.5 \%)$. Conclusion. There are varying results of the clinical characteristics of patients with brain abscesses, and indicate the natural course of this disease.
\end{abstract}

Keywords: brain abscess, patient's characteristics, CT scan

\section{INTRODUCTION}

Central nervous system (CNS) infection is one of the main sources of morbidity today. The presence of new, broader spectrum antibiotics as well as improved clinical imaging technology and intensive care facilities has changed the history of previous CNS infection management. It is known that the brain does not have its own immune system but the blood brain barrier is predominantly immune to infection. However, it is not uncommon for these infections to cause serious illness in the body. Brain abscess is one of the serious dis- eases that affect the CNS (1). A brain abscess is a collection of pus, immune cells, and other materials commonly caused by bacterial or fungal infection in the brain parenchyma. When a part of the brain becomes infected through blood or directly, it becomes swollen and inflamed. Infected brain cells, white blood cells, live and dead bacteria, or fungi collect in this area of the brain. The surrounding tissue will form a mass (abscess) (2-5). Often the source of infection is not found, but the most common source is infection of the lungs and rarely occurs from heart infection. Several factors 
can increase the risk of developing a brain abscess, including a weak immune system (HIV / AIDS patients), a history of chronic diseases such as cancer, taking immunosuppressants (corticosteroids or chemotherapy), and congenital heart disease (2).

Undiagnosed or untreated brain abscess has very high morbidity and mortality. Brain abscess morbidity reaches $46 \%$ with a mortality rate of $13.58 \%$. Complications caused by brain abscess include septicemia, neurological deficits, meningitis, ventriculitis, intracranial vascular thrombosis, brain herniation, seizures, and increased intracranial pressure $(2,6,7)$. Brain abscess has a higher prevalence in developing countries than in developed countries. This is due to differences in socio-economic conditions that occur in these countries (8). Indonesia has reported several cases of brain abscess, but there is no definite national data (9). Each region has its own characteristics of patients so that it requires different management.

The need for science encourages research on certain health issues. To determine the characteristics of a patient with a brain abscess, data is needed to describe this.

\section{MATERIAL AND METHODS}

This research is a descriptive observational study with a cross sectional approach to determine the proportion and characteristics of patients with brain abscesses at Sanglah General Hospital in 2019-2020. This research was conducted at Sanglah General Hospital Denpasar by taking secondary data from the Medical Record Installation. The population in this study were all patients with brain abscesses who were registered at the Sanglah General Hospital Medical Record Installation, Denpasar, Bali. The sampling technique used in this study was total sampling technique. Subjects taken from the population were those who met the inclusion criteria, namely medical record data that show that the patients had been diagnosed with brain abscess by doctors at Sanglah General Hospital Denpasar in 2019-2020, and were in accordance with the research variables, and did not meet the exclusion criteria in the form of incomplete medical record data of patients with brain abscess disease at Sanglah General Hospital Denpasar in 2019-2020.
This research has received permission from the Research Ethics Commission of Udayana Medical Faculty/Sanglah Hospital Denpasar number 2110/ UN14.2.2.VII.14/LT/2020.

\section{RESULTS}

Table 1 shows the demographic characteristics of patients. Most of the patients were male $(n=26$, $63.4 \%)$.

TABLE 1. Demographic characteristics of patients

\begin{tabular}{|c|c|c|c|}
\hline \multicolumn{2}{|c|}{ Sociodemographic Ccharacteristics } & N & \% \\
\hline Gender & Male & 26 & 63.4 \\
& Female & 15 & 36.6 \\
\hline Total & & 41 & 100.0 \\
\hline Age & 20-39 Years & 16 & 39.0 \\
& 40-59 Years & 16 & 39.0 \\
& $>60$ Years & 9 & 22.0 \\
& & & \\
\hline Total & & 41 & 100.0 \\
\hline
\end{tabular}

The main complaints of the patient are shown in Table 2. Most of the patients had the main complaints in the form of decreased consciousness $(n=$ $23,56.1 \%)$, weakness of half of the body $(n=8$, $19.5 \%)$ and headache $(n=6,14.6 \%)$.

TABLE 2. Main complaints of patients

\begin{tabular}{|c|c|c|c|}
\hline \multicolumn{2}{|c|}{ Main complaints } & N & $\%$ \\
\hline Main complaints & Decrease in awareness & 23 & 56.1 \\
& headache & 6 & 14.6 \\
& Hemiparesis & 8 & 19.5 \\
& Seizures & 1 & 2.4 \\
& Vomiting & 1 & 2.4 \\
& Slurred speech & 2 & 4.9 \\
\hline Total & & 41 & 100.0 \\
\hline
\end{tabular}

Data regarding the results of vital signs examination on patients can be seen in Table 3. Most of the patients have blood pressure, respiratory rate and pulse rate, and body temperature within normal limits. Patients also have a fairly mild pain intensity.

TABLE 3. Vital signs of patients

\begin{tabular}{|c|c|c|}
\hline Vital signs & Mean & Median \\
\hline Systolic blood pressure & $124.39 \mathrm{mmHg}$ & $120.0 \mathrm{mmHg}$ \\
Diastolic blood pressure & $77.68 \mathrm{mmHg}$ & $80.00 \mathrm{mmHg}$ \\
Respiratory rate & $21.53 \times /$ minute & $20.00 \mathrm{x} / \mathrm{minut}$ \\
Pulse & $84.14 \times /$ minute & $84.00 \mathrm{x} /$ minute \\
Body temperature & $36.79 \mathrm{C}$ & $36.50 \mathrm{C}$ \\
GCS & 12.31 & 14.00 \\
Pain scale & 1.34 & 1.00 \\
\hline
\end{tabular}

Neurological symptoms found in patients are shown in Table 4. Most of the patients had neuro- 
logical symptoms in the form of hemiparesis ( $\mathrm{n}=$ $33,32.3 \%), 7$ nerve paresis $(\mathrm{n}=25,24.5 \%)$, and Babinski's sign $(n=15,23.0 \%)$.

TABLE 4. Neurological symptoms

\begin{tabular}{|c|c|c|c|}
\hline \multicolumn{2}{|c|}{ Neurological symptoms } & N & $\%$ \\
\hline Neurological & Hemiparesis & 33 & 2.3 \\
symptoms & Diparesis & 3 & 2.9 \\
& Stiff neck & 4 & 3.9 \\
& Cephalgia & 11 & 10.7 \\
& Nerve paresis 3 & 1 & 0.9 \\
& Nerve paresis 6 & 1 & 0.9 \\
& Nerve paresis 7 & 25 & 24.5 \\
& Nerve paresis 12 & 8 & 7.8 \\
& Babinski & 15 & 23.0 \\
& Seizure & 1 & 0.9 \\
\hline
\end{tabular}

Table 5 shows the location of the abscess found in the patient. In general, most abscesses were in the right hemisphere $(n=38,59.4 \%)$. Specifically, the abscess locations were found mostly on the right frontal $(n=9,14.06 \%)$, right parietal $(n=9$, $14.06 \%)$, and left parietal $(n=9,14.06 \%)$.

TABLE 5. Location of patient's brain abscess

\begin{tabular}{|c|c|c|}
\hline Abscess location & N & \% \\
\hline Right temporal & 6 & 9.40 \\
Left temporal & 3 & 4.70 \\
Right frontal & 9 & 14.06 \\
Left frontal & 6 & 9.40 \\
Right occipital & 2 & 3.13 \\
Left occipital & 2 & 3.13 \\
Right parietal & 9 & 14.06 \\
Left parietal & 9 & 14.06 \\
Right cerebellum & 2 & 3.13 \\
Right ventricle & 1 & 1.56 \\
Left ventricle & 1 & 1.56 \\
Left thalamus & 1 & 1.56 \\
Right tempo parietal & 4 & 6.20 \\
Right tempo occipital & 1 & 1.56 \\
Left tempo occipital & 1 & 1.56 \\
Right front occipital & 1 & 1.56 \\
Right frontotemporal & 1 & 1.56 \\
Left frontotemporal & 1 & 1.56 \\
Left frontoparietal & 2 & 3.13 \\
Right temporoparietal occipital & 1 & 1.56 \\
Right front temporoparietal & 1 & 1.56 \\
\hline
\end{tabular}

Results of patients' CT scan of can be seen in Table 6. Most of the patient's CT scan results showed a rim of contrast enhancement $(\mathrm{n}=26$, $63.4 \%)$, cerebral edema $(n=31,75.6 \%)$, and normal sulcus gyri $(n=21,51.2 \%)$. Meanwhile, only a small proportion of patients showed leptomeningeal enhancement $(\mathrm{n}=7,17.1 \%)$ and a calcification $(\mathrm{n}=2,4.8 \%)$.

History of surgical procedures in patients is shown in Table 7 . There were 8 patients with a history of surgical procedures, and 4 of them with a history of craniotomy.
TABLE 6. Other CT scan examination results on patients

\begin{tabular}{|c|c|c|c|}
\hline \multicolumn{2}{|c|}{ Ct scan examination } & \multirow{2}{*}{$\begin{array}{l}\mathbf{N} \\
26 \\
15\end{array}$} & \multirow{2}{*}{$\begin{array}{c}\% \\
63.4 \\
36.6 \\
\end{array}$} \\
\hline $\begin{array}{l}\text { Rim contrast } \\
\text { enhancement }\end{array}$ & $\begin{array}{l}\text { Exist } \\
\text { None }\end{array}$ & & \\
\hline Total & & 41 & 100.0 \\
\hline $\begin{array}{l}\text { Leptomeningeal } \\
\text { enhancement }\end{array}$ & $\begin{array}{l}\text { Exist } \\
\text { None }\end{array}$ & $\begin{array}{c}7 \\
34 \\
\end{array}$ & $\begin{array}{l}17.1 \\
82.9\end{array}$ \\
\hline Total & & 41 & 100.0 \\
\hline Edema cerebri & $\begin{array}{l}\text { Exist } \\
\text { None }\end{array}$ & $\begin{array}{l}31 \\
10 \\
\end{array}$ & $\begin{array}{l}75.6 \\
24.4 \\
\end{array}$ \\
\hline Total & & 41 & 100.0 \\
\hline Scalp & $\begin{array}{c}\text { Normal } \\
\text { Not normal }\end{array}$ & $\begin{array}{c}40 \\
1 \\
\end{array}$ & $\begin{array}{c}97.5 \\
2.5 \\
\end{array}$ \\
\hline Total & & 41 & 100.0 \\
\hline Sulcus gyri & $\begin{array}{c}\text { Normal } \\
\text { Move closer } \\
\text { Narrowed }\end{array}$ & $\begin{array}{c}21 \\
16 \\
4 \\
\end{array}$ & $\begin{array}{c}51.2 \\
39.0 \\
9.8 \\
\end{array}$ \\
\hline Total & & 41 & 100.0 \\
\hline Midline deviation & $\begin{array}{l}\text { Exist } \\
\text { None }\end{array}$ & $\begin{array}{l}14 \\
27 \\
\end{array}$ & $\begin{array}{l}34.1 \\
65.9 \\
\end{array}$ \\
\hline Total & & 41 & 100.0 \\
\hline Calcification & $\begin{array}{l}\text { Exist } \\
\text { None }\end{array}$ & $\begin{array}{c}2 \\
39\end{array}$ & $\begin{array}{c}4.8 \\
95.2\end{array}$ \\
\hline Total & & 41 & 100.0 \\
\hline Pons & $\begin{array}{c}\text { Normal } \\
\text { Not Normal }\end{array}$ & $\begin{array}{c}40 \\
1 \\
\end{array}$ & $\begin{array}{l}97.5 \\
2.5 \\
\end{array}$ \\
\hline Total & & 41 & 100.0 \\
\hline Cerebellum & $\begin{array}{c}\text { Normal } \\
\text { Not normal }\end{array}$ & $\begin{array}{c}40 \\
1 \\
\end{array}$ & $\begin{array}{l}97.5 \\
2.5 \\
\end{array}$ \\
\hline Total & & 41 & 100.0 \\
\hline Calvaria & $\begin{array}{c}\text { Normal } \\
\text { Not normal }\end{array}$ & $\begin{array}{c}41 \\
0 \\
\end{array}$ & $\begin{array}{c}100.0 \\
0.0\end{array}$ \\
\hline Total & & 41 & 100.0 \\
\hline Basis cranii & $\begin{array}{c}\text { Normal } \\
\text { Not normal }\end{array}$ & $\begin{array}{c}41 \\
0 \\
\end{array}$ & $\begin{array}{c}100.0 \\
0.0\end{array}$ \\
\hline Total & & 41 & 100.0 \\
\hline Herniation & $\begin{array}{l}\text { Exist } \\
\text { None }\end{array}$ & $\begin{array}{c}6 \\
35\end{array}$ & $\begin{array}{l}17.1 \\
82.9\end{array}$ \\
\hline Total & & 41 & 100.0 \\
\hline
\end{tabular}

TABLE 7. History of surgical procedures in patients

\begin{tabular}{|c|c|c|}
\hline Surgical procedures & N & $\%$ \\
\hline Craniotomy & 4 & 50 \\
Vp shunt & 1 & 12.5 \\
Abscess trepanation & 1 & 12.5 \\
Pus aspiration & 1 & 12.5 \\
Resection & 1 & 12.5 \\
\hline
\end{tabular}

Data related to the history of other patients is shown in Table 8. Sinusitis is the most common medical history in patients $(\mathrm{n}=21,29.5 \%)$, followed by diabetes mellitus $(\mathrm{n}=11,15.3 \%) \mathrm{m}$ and toxoplasmosis $(\mathrm{n}=9,12.5 \%)$.

\section{DISCUSSION}

Patients with brain abscess in this study were dominated by men. This is in line with the prevalence data which stated that brain abscess patients 
TABLE 8. History of other diseases in patients

\begin{tabular}{|c|c|c|c|}
\hline \multicolumn{2}{|c|}{ Other diseases } & N & $\%$ \\
\hline Other & Toxoplasmosis & 9 & 12.5 \\
diseases & HIV & 8 & 11.1 \\
& Diabetes mellitus & 11 & 15.3 \\
& Hydrocephalus & 3 & 4.2 \\
& Meningitis & 4 & 5.5 \\
& Brain tumor & 2 & 2.7 \\
& Kidney failure & 2 & 2.7 \\
& Hypertension & 3 & 4.2 \\
& COVID-19 & 2 & 2.7 \\
& SLE & 1 & 1.4 \\
& UTI & 1 & 1.4 \\
& Ear infection & 2 & 2.7 \\
& Heart disease & 1 & 1.4 \\
& TB & 2 & 2.7 \\
& Sinusitis & 21 & 29.5 \\
\hline Total & & 72 & 100.0 \\
\hline
\end{tabular}

are more dominant in men than women with a ratio varying between $2: 1$ and $3: 1$. In addition, there is no significant relationship between geographic and seasonal differences with the prevalence of brain abscess. Brain abscess accounts for a disproportionate percentage of intracranial lesions in developing countries compared to developed countries $(10,11)$.

The age characteristics in this study are also in line with the data which stated that the age range of brain abscess patients ranges from 24 to 57 years. The average age of onset is higher in developed than developing countries. This relationship is not yet clearly defined, but may be related to reduced immune conditions in the elderly as well as greater life expectancy and lower rates of traumatic brain injury in younger individuals in developed countries (12).

The main complaint most often experienced by patients in this study was a decrease in the level of consciousness by 23 people (56.1\%), followed by half-body weakness (hemiplegia), headache, slurred speech, seizures, and vomiting. This clinical manifestation is in accordance with the research conducted by Patel and Clifford, but in that study the most common sign was headache.

The clinical manifestations of brain abscess vary and are not specific depending on the location, size, stage and number of lesions, bacterial malignancy, degree of brain edema, the patient's response to infection, and the patient's age. If the progression of the abscess continued, the complaints would be more clearly seen in the patient. There is a classic triad showing brain abscesses, namely fever, headache, and decreased level of fo- cal consciousness, but recent reports suggest that this constellation only occurs in a small proportion of cases $(5,12,13)$.

Based on the results of the study, Table 3 shows the data regarding the status of vital signs of Sanglah General Hospital patients, Denpasar for the period 2019-2020 with parameters in the form of mean and mean values. The values for blood pressure (systolic and diastolic), pulse rate, and body temperature are known to be within the normal range. An increase in the respiratory rate from the normal range $(18-20 \mathrm{x} / \mathrm{min})$ can be caused by an infection-related condition (14). These results are also directly proportional to previous case studies which reported a similar condition in the form of an increase in respiratory rate of $28 \mathrm{x} / \mathrm{min}$ ute, especially in the condition of Streptococcus sp. (15). The decrease in the mean GCS is known to be in a state of apathy $(12,13)$. A similar reduction was also found in previous studies where $42 \%$ of the total patients had GCS status $<14$ (16). Recent retrospective studies also showed similar results, with $48.14 \%$ of the total patients having a GCS status $<14$ and associated with a poor prognosis (17). The study by Landriel et al. reported a median GCS of 15 patients with the condition that $79.6 \%$ of patients were on GCS 14-15 and only two patients had GCS $<8$ (18). The study by Zhang et al. reported that $13.33 \%$ of patients had GCS $<13$ during the admission process of a total of 60 patients (19). The study by Helweg-Larsen et al. reported that $77 \%$ of patients had a GCS of $12-15,10 \%$ had a GCS of $8-11$, and $9 \%$ had a GCS of $<8$ of a total of 102 patients (6). There is also another study which reported that $11.53 \%$ of the total patients had GCS < 8 (20). Another study also reported altered consciousness and neurological deficits in $43 \%$ and $48 \%$ of total patients, respectively (21). GCS values are also known to influence the clinical outcome of the intracranial surgery caused by bacterial infection (22) Decreased GCS and mental state are associated with a poor prognosis for bacterial brain abscess (12). Pain assessment has a mean of 1.34 with a susceptible value of 1-10. Pain characteristics are generally localized to the area around the lesion with a gradual or sudden onset. Pain sensation is also generally not decreased with pain-reducing drugs (5).

Based on the results of the study, table 4 shows that the highest neurological symptom experienced 
by patients of brain abscess at Sanglah General Hospital Denpasar in 2019 was hemiparesis, which was 33 people $(32.3 \%)$ while the lowest neurological symptom experienced by patients was seizures by 1 person $(0.9 \%)$. There is a case report which stated that a man with a brain abscess found evidence of right sided dysarthria and hemiparesis (23). The results of this study are also in line with studies conducted by Chang et al., with the same results, namely that the most common clinical manifestation found is hemiparesis, followed by fever, altered consciousness, headache, septic shock, and the least common is seizure (24). However, the results of this study are not in line with the results obtained by Hsu et al., who stated that the least clinical manifestation found was hemiparesis. This is probably due to differences in the number of patients who were used as subjects, differences in demographics, and locations where the study was conducted (25).

The location of infection in a brain abscess can vary, but the most common intracranial sites are the frontal - parietal, frontal - temporal, cerebellum, occipital and partial lobes (26). The location of the brain abscess is closely related to the cause of the infection. Autogenic abscesses are more common in the temporal lobe and cerebellum, whereas abscesses due to sinus infections are predominantly frontal (12). Brain abscess is known to occur more frequently in the left hemisphere than in the right hemisphere for which the cause is not clearly defined $(26,27)$.

Based on the results of the study, Table 6 shows the data on the results of CT scans in patients. CT scan can be used for early detection, locale, characteristics, determination of the number, size and stage of the abscess quickly so that it is very helpful in planning treatment and further action. The results of the CT scan of patients with brain abscesses in Sanglah General Hospital in 2019-2020 showed that more cases were not accompanied by a hernia ( $82.9 \%$ of people), this is in line with a previous analysis by Muzumdar et al., of 289 cases of pyogenic abscess in Seth. GS Medical College and King Edward VII Memorial Hospital, Mumbai, India during a period of 7 years (1999-2006) there were 3 out of 289 patients who died came in a coma with transtentorial herniation (28).

Imaging findings depend on the stage of the lesion. Brain abscess cases are common with rim-en- hancing lesions with either CT or MRI. Rim-enhancing is typically thin $(2-7 \mathrm{~mm})$, convex in shape, and has fine outer and inner margins. In this study, more were found of rim contrast enhancement (63.4\% of patients). Research by Britt et al. reported that the CT findings in early-stage cerebrum were unevenly elevated and subsequently progressed to rim-enhancing in advanced cerebrum which subsequently formed brain abscesses (36).

In this study, leptomeningeal enhancement was only found in 7 patients (17.1\%). Leptomeningeal enhancement is usually followed by meningitis and meningoencephalitis caused by viruses, bacteria, or fungi. Leptomeningeal enhancement is an increase in pia-arachnoid which will then fill the subarachnoid space of the sulcus and water tank and will then describe "gyriform" or "serpentine". Sulcus gyri in patients in this study were dominated by normal conditions (51.2\% of people) (28). The study of Bokhari and Mesfin reported (65\%) a change in mental state of lethargy to coma is an indication of the occurrence of cerebral edema and a poor prognosis. CT examination of an advanced abscess shows a progressive decrease in edema and mass due to steroid administration (2).

Based on the results of the study, Table 7 shows the data regarding the history of the management of surgical procedures in patients. Surgical procedures generally aim to reduce pressure (decompression) in the area of the lesion, reduce intracranial pressure, and eradicate the presence of both primary and secondary infection (29). The craniotomy procedure had the highest prevalence found in four patients or by $50 \%$ with other procedures, namely VP shunt, abscess trepanation, pus aspiration, and resection each having a prevalence of $12.5 \%$. In previous studies, a craniotomy was generally required for a traumatic brain abscess to remove foreign bodies or residual bone. Craniotomy with excision is generally performed when the abscess does not respond to pus aspiration (29). The study by Tan et al. used a total of 51 cases of brain abscess patients with therapeutic characteristics in the form of craniectomy accompanied by excision (54.9\% of patients) and aspiration (45.1\% of patients), and results in the form of improved neurological function and better radiological clearance and significant decreased rates of re-surgery $(p<0.05)$ in the craniotomy group compared to 
aspiration without any significant differences in mortality and morbidity between the two treatment groups (30). Another retrospective study reported that at least $53 \%$ of patients with primary brain abscess underwent a craniotomy procedure (5). A recent study by Makwana et al. reported that $72 \%$ of patients underwent craniotomy and $28 \%$ of patients underwent aspiration (31). Pus aspiration is a safe and relatively easy procedure that generally results in a rapid drop in intracranial pressure while identifying the causal organism. Research by Gadgil et al. reported that $27 \%$ of patients receiving open aspiration by excision had the highest prevalence of $67 \%$ of patients (16). Research by Zhang et al., at the General Hospital of Tianjin Medical University, during the period 1952-2014, reported that 253 patients received aspiration, 211 excisions, and 92 received both out of a total of 620 patients (32). Previous studies also reported that as many as $60 \%$ of patients used the aspiration method (stereotactically guided aspiration) and $30 \%$ received craniotomy from a total of 60 patients (19). Another study also showed results similar to stereotactically guided aspiration were accepted in $74.6 \%$ of patients, while $25.4 \%$ of patients received craniotomy (19). Study by HelHospital reported that $67 \%$ of patients received aspiration, $20 \%$ received a craniotomy, and 13\% did not receive surgery (antibiotics only) from a total of 102 patients (6).

Based on the results of the study, Table 8 shows that the history of medical treatment and other disease history experienced by brain abscess patients at Sanglah General Hospital Denpasar in 20192020 was sinusitis, which was 21 people $(29.5 \%)$, weg-Larsen et al. at the Rigshospitalet University

followed by diabetes mellitus in 11 people (15.3\%) with a history of medical action and other diseases, the lowest was systemic lupus erythematosus (SLE), urinary tract infections (UTI), and heart disease in 1 person (1.4\%) each. This is in accordance with previous references which stated that important risk factors for brain abscess are diabetes mellitus, liver cirrhosis, malignancy, malnutrition, and immunosuppression $(23,34)$. The results of this study are also in line with Ong et al., who stated that the most frequently found history of other diseases in brain abscess patients is lung disease, diabetes mellitus, hypertension, and hepatitis (35).

\section{CONCLUSIONS}

The proportion of patients with brain abscesses in Sanglah General Hospital in 2019-2020 was 41 people. Characteristics of patients with brain abscesses at Sanglah General Hospital based on socio-demographic data are dominantly male, commonly occurred in the age range $<60$ years, the main complaint experienced was a decrease in the level of consciousness, vital signs were mostly included in the normal range, neurological symptoms that often appeared were hemiparesis, followed by nerve paresis 7 , and nerve paresis 12 , the parietal area both right and left and right frontal area are were most common locations for abscesses, from the results of CT scans Patients often showed rim enhancement and edema cerebri, craniectomy is the most commonly performed surgical procedure for people with brain abscesses. Patients also have a history of other diseases including sinusitis, diabetes mellitus, toxoplasma and HIV.

Conflict of interest: none declared Financial support: none declared

\section{REFERENCES}

1. Muzumdar D. Central nervous system infections and the neurosurgeon: a perspective. Int J Surg. 2011;9(2):113-6.

2. Bokhari MR, Mesfin FB. Brain Abscess. [Updated 2020 Jun 30]. In: StatPearls [Internet]. Treasure Island (FL): StatPearls Publishing; 2021. Available at: https://www.ncbi.nlm.nih.gov/books/NBK441841/.

3. Chen M, Low DCY, Low SYY, Muzumdar D, Seow WT. Management of brain abscesses: where are we now? Childs Nerv Syst. 2018 Oct;34(10):1871-1880.

4. Widdrington JD, Bond $\mathrm{H}, \mathrm{Schwab} \mathrm{U}$, Price DA, Schmid ML, McCarron B, Chadwick DR, Narayanan M, Williams J, Ong E. Pyogenic brain abscess and subdural empyema: presentation, management, and factors predicting outcome. Infection. 2018 Dec;46(6):785-792. Ryang YM, Meyer B, Gempt J. Clinical characteristics and course of primary brain abscess. Acta Neurochir (Wien). 2018 Oct; 160(10):2055-2062.

6. Helweg-Larsen J, Astradsson A, Richhall H, Erdal J, Laursen A, Brennum J. Pyogenic brain abscess, a 15 year survey. BMC Infect Dis. 2012 Nov 30;12:332.

7. Chowdhury FH, Haque MR, Sarkar MH, Chowdhury SMNK, Hossain Z, Ranjan S. Brain abscess: surgical experiences of 162 cases. Neuroimmunol Neuroinflammation 2015;2:153-161.

8. Nathoo N, Nadvi SS, Narotam PK, van Dellen JR. Brain abscess: management and outcome analysis of a computed tomography era
5. Lange N, Berndt M, Jörger AK, Wagner A, Wantia N, Lummel N, 
experience with 973 patients. World Neurosurg. 2011 May-Jun; 75(5-6):716-26.

9. Samatra P. Abses Serebri. In: The 6th Bali Neurology Update 2018 Tropical Disease and Neuropediatric Cases: Revisiting (Re)Emerging Issues with National Priorities. Udayana University Press; 2018.

10. Gorji GRS, Rassouli M, Staji H. Prevalence of cerebral toxoplasmosis among slaughtered sheep in Semnan, Iran. Ann Parasitol. 2018;64(1):37-42.

11. Maher G, Beniwal M, Bahubali V, Biswas S, Bevinahalli N, Srinivas D, Siddaiah N. Streptococcus pluranimalium: Emerging Animal Streptococcal Species as Causative Agent of Human Brain Abscess. World Neurosurg. 2018 Jul;115:208-212.

12. Patel K, Clifford DB. Bacterial brain abscess. Neurohospitalist. 2014 Oct;4(4):196-204.

13. Zumla A. Mandell, Douglas, and Bennett's principles and practice of infectious diseases. Lancet Infect Dis. 2010 May;10(5):303-4.

14. Minelli E, Sassun TE, Papi M, Palmieri V, Palermo F, Perini G, Antonelli M, Gianno F, Maulucci G, Ciasca G, De Spirito M. Nanoscale mechanics of brain abscess: An atomic force microscopy study. Micron. 2018 Oct;113:34-40.

15. Belodu R, S N, R R, Kumar R, B A C. A pneumococcal brain abscess: a case report. J Clin Diagn Res. 2013 Aug;7(8):1694-5.

16. Gadgil N, Patel AJ, Gopinath SP. Open craniotomy for brain abscess: A forgotten experience? Surg Neurol Int. 2013 Mar 25:4:34.

17. Asquier-Khati A, Deschanvres C, Boutoille D, Lefebvre M, et al.; Nantes Brain Abscesses study group. Switch from parenteral to oral antibiotics for brain abscesses: a retrospective cohort study of 109 patients. J Antimicrob Chemother. 2020 Oct 1;75(10):3062-3066.

18. Landriel F, Ajler P, Hem S, Bendersky D, Goldschmidt E, Garategui L, Vecchi E, Konsol O, Carrizo A. Supratentorial and infratentorial brain abscesses: surgical treatment, complications and outcomes--a 10-year single-center study. Acta Neurochir (Wien). 2012 May;154(5):903-11.

19. Chiu TH, Haliza G, Lin YH, Hung TH, Hsu JJ, Hsieh TT, Lo LM. A retrospective study on the course and outcome of fetal ventriculomegaly. Taiwan J Obstet Gynecol. 2014 Jun;53(2):170-7.

20. Radoi M, Ciubotaru V, Tataranu L. Brain abscesses: clinical experience and outcome of 52 consecutive cases. Chirurgia (Bucur). 2013 Mar-Apr;108(2):215-25.

21. Brouwer MC, Coutinho JM, van de Beek D. Clinical characteristics and outcome of brain abscess: systematic review and metaanalysis. Neurology. 2014 Mar 4;82(9):806-13.

22. Idowu OE, Majekodunmi AA. Relationship between demography, etiology, level of consciousness, and outcome of surgical intracranial suppurations of bacterial origin in a tropical tertiary center. Asian $\mathrm{J}$ Neurosurg. 2016 Jan-Mar;11(1):41-5.

23. Hernandez Jimenez JM, Vahdat K, Serrano Santiago IA, Morales Hernandez MDM, Isache CL, Sands M. Thalamic bacterial abscess presenting with hemiparesis and expressive aphasia. IDCases. 2018 Jun 28;13:e00417.

24. Chang YT, Lu CH, Chuang MJ, Huang CR, Chuang YC, Tsai NW, Chen SF, Chang CC, Chang WN. Supratentorial deep-seated bacterial brain abscess in adults: clinical characteristics and therapeutic outcomes. Acta Neurol Taiwan. 2010 Sep;19(3):178-83.

25. Hsu CW, Lu CH, Chuang MJ, Huang CR, Chuang YC, Tsai NW, Chen SF, Chang CC, Chang WN. Cerebellar bacterial brain abscess: report of eight cases. Acta Neurol Taiwan. 2011 Mar;20(1):47-52.

26. Brook I. Microbiology and treatment of brain abscess. J Clin Neurosci. 2017 Apr;38:8-12.

27. Lu CH, Chang WN, Lin YC, Tsai NW, Liliang PC, Su TM, Rau CS, Tsai YD, Liang CL, Chang CJ, Lee PY, Chang HW, Wu JJ. Bacterial brain abscess: microbiological features, epidemiological trends and therapeutic outcomes. QJM. 2002 Aug;95(8):501-9.

28. Muzumdar D, Jhawar S, Goel A. Brain abscess: an overview. Int J Surg. 2011;9(2):136-44.

29. Alvis Miranda H, Castellar-Leones SM, Elzain MA, Moscote-Salazar LR. Brain abscess: Current management. J Neurosci Rural Pract. 2013 Aug;4(Suppl 1):S67-81.

30. Tan WM, Adnan JS, Mohamad Haspani MS. Treatment outcome of superficial cerebral abscess: an analysis of two surgical methods. Malays J Med Sci. 2010 Jan;17(1):23-9.

31. Makwana M, Merola JP, Bhatti I, Patel CK, Leach PA. Towards improved outcome in children treated surgically for spontaneous intracranial suppuration in South Wales. Br J Neurosurg. 2021 Jan 11:1-4.

32. Zhang Z, Cai X, Li J, Kang X, Wang H, Zhang L, et al. Retrospective analysis of 620 cases of brain abscess in Chinese patients in a single center over a 62-year period. Acta Neurochir (Wien). 2016 Apr;158(4):733-739.

33. Landriel F, Ajler P, Hem S, Bendersky D, Goldschmidt E, Garategui L, Vecchi E, Konsol O, Carrizo A. Supratentorial and infratentorial brain abscesses: surgical treatment, complications and outcomes--a 10-year single-center study. Acta Neurochir (Wien). 2012 May;154(5):903-11.

34. Karageorgiou I, Chandler C, Whyte MB. Silent diabetes mellitus, periodontitis and a new case of thalamic abscess. BMJ Case Rep. 2014 Jul 21;2014:bcr2014204654.

35. Ong CT, Tsai CF, Wong YS, Chen SC. Epidemiology of brain abscess in Taiwan: A 14-year population-based cohort study. PLOS One. 2017 May 9;12(5):e0176705.

36. Britt RH, Enzmann DR, Yeager AS. Neuropathological and computerized tomographic findings in experimental brain abscess. J Neurosurg. 1981 Oct;55(4):590-603. 